\title{
PENGETAHUAN DAN SIKAP IBU HAMIL TENTANG MANFAAT MENGKONSUMSI TABLET FE DI WILAYAH KERJA PUSKESMAS KARANG REJO KOTA TARAKAN
}

\author{
Yogho Prastyo', Mega Octamelia ${ }^{2}$, Imelda Triyana ${ }^{3}$ \\ 1,2,3 Jurusan Kebidanan Fakultas Ilmu Kesehatan Universitas Borneo Tarakan \\ *Email : yoghoprastyo@borneo.ac.id
}

\begin{abstract}
Abstrak
Berdasarkan data Dinas Kesehatan Kota Tarakan tahun 2019, terdapat 17,95\% ibu hamil yang mengalami anemia. Kekurangan zat besi pada ibu hamil menyebabkan anemia yang dapat meningkatkan frekuensi komplikasi pada kehamilan dan persalinan. Penelitian ini bertujuan untuk mengetahui gambaran pengetahuan dan sikap ibu hamil tentang pentingnya mengkonsumsi tablet zat besi selama kehamilannya di Puskesmas Karang Rejo pada bulan Mei tahun 2019. Jenis penelitian bersifat deskriptif dengan populasi sebanyak 164 orang dan diperoleh 50 sampel yang ditentukan secara purposive sampling. Pengambilan data dengan menggunakan kuisioner. Hasil penelitian menunjukkan bahwa pengetahuan ibu hamil tentang pentingnya mengkonsumsi tablet zat besi selama kehamilannya, diperoleh sebanyak 27 responden (54\%) yang berpengetahuan baik, dan sebanyak 23 responden (46\%) yang berpengetahuan kurang baik. Sedangkan sikap ibu hamil terhadap pentingnya mengkonsumsi tablet zat besi selama kehamilannya, diperoleh sebanyak 33 responden (66\%) memiliki sikap baik, dan sebanyak 17 responden $(34 \%)$ memiliki sikap sangat baik.
\end{abstract}

Kata Kunci : Ibu Hamil, Pengetahuan, Sikap, Tablet Fe

\begin{abstract}
Based on data from the Tarakan City Health Office in 2019, there were $17.95 \%$ of pregnant women who were anemic.. Iron deficiency in pregnant women causes anemia which can increase the frequency of complications in pregnancy and childbirth. This study aims to describe the knowledge and attitudes of pregnant women about the importance of consuming iron tablets during their pregnancy at Puskesmas Karang Rejo in May 2019. This research is descriptive research with a population of 164 people and obtained 50 samples determined by purposive sampling. Retrieving data using questionnaires. The results showed that the knowledge of pregnant women about the importance of consuming iron tablets during pregnancy, obtained 27 respondents (54\%) who were wellinformed, and as many as 23 respondents (46\%) were less knowledgeable. While the attitude of pregnant women towards the importance of consuming iron tablets during pregnancy, 33 respondents (66\%) had a good attitude, and as many as 17 respondents (34\%) had a very good attitude.
\end{abstract}

Keywords : Attitude, Fe Tablets, Knowledge, Pregnant women 
Yogho Prastyo, Mega Octamelia, Imelda Triyana. Pengetahuan Dan Sikap Ibu Hamil Tentang Manfaat Mengkonsumsi Tablet Fe Di Wilayah Kerja Puskesmas Karang Rejo Kota

Tarakan

\section{Pendahuluan}

Zat besi $(\mathrm{Fe})$ merupakan mikroelemen esensial penting bagi pembentukan hemoglobin di dalam tubuh. Kekurangan zat besi merupakan penyebab utama anemia. Anemia menjadi masalah gizi yang banyak terjadi pada ibu hamil, yang merupakan masalah gizi mikro terbesar dan tersulit diatasi di seluruh dunia (Tanziha, Utama, \& Rosmiati, 2017) Pada ibu hamil, anemia berkontribusi besar terhadap peningkatan frekuensi komplikasi pada kehamilan dan persalinan. Kebutuhan Ibu hamil akan zat besi meningkat (untuk pembentukan plasenta dan sel darah merah) yaitu rata-rata 80-1040 mg (Susiloningtyas, 2012). Upaya yang dilakukan untuk memenuhi kebutuhan zat besi bagi ibu selama masa kehamilannya yaitu dengan suplementasi tablet Fe. Suplementasi tablet $\mathrm{Fe}$ adalah salah satu program pencegahan dan penanggulangan anemia defisiensi besi yang paling efektif meningkatkan kadar hemoglobin pada ibu hamil dan dapat menurunkan prevalensi anemia pada ibu hamil sebesar 20-25\% (Rizki, Lipoeto, \& Ali, 2018).

Berdasarkan hasil Riset Kesehatan Dasar (Riskesdas) tahun 2018, presentasi ibu hamil yang mengalami anemia meningkat dibandingkan hasil Riset Kesehatan Dasar (Riskesdas) tahun 2013 yaitu sebesar 37,1 persen. (Riskesdas, 2018).

Merujuk pada Peraturan Menteri Kesehatan Republik Indonesia Nomor 88 Tahun 2014 tentang "Standar Tablet Tambah Darah bagi Ibu Wanita Usia Subur dan Ibu Hamil" yang menyatakan bahwa wanita usia subur dan ibu hamil rentan terhadap kekurangan gizi besi yang dapat menyebabkan anemia, oleh karena itu puskesmas berperan dalam memberikan penyuluhan kepada ibu hamil tentang pentingnya mengkonsumsi tablet zat besi dan rutin memberikan tablet zat besi sesuai standar minimal 90 tablet selama masa kehamilan (Peraturan Menteri Kesehatan No. 88 tahun 2014).

Berdasarkan data Dinas Kesehatan Kota Tarakan tahun 2019 presentasi ibu hamil yang mengalami anemia sebesar $17,95 \%$ sedangkan di tahun 2018 presentase ibu hamil yang mengalami anemia sebesar 16,85\%. Dari data yang diperoleh dari Dinas Kesehatan Kota Tarakan tahun 2019, Puskesmas tertinggi dengan angka kejadian anemia di Kota 
Yogho Prastyo, Mega Octamelia, Imelda Triyana. Pengetahuan Dan Sikap Ibu Hamil Tentang Manfaat Mengkonsumsi Tablet Fe Di Wilayah Kerja Puskesmas Karang Rejo Kota

Tarakan

Tarakan adalah Puskesmas Karang Rejo sebanyak 27 ibu hamil (32\%). Adapun cakupan pemberian tablet zat besi $(\mathrm{Fe} 3)$ pada ibu hamil di Kota Tarakan tahun 2019 terdapat 5.464 ibu hamil dan 31,99\% ibu yang mendapat tablet Fe sedangkan pada tahun 2018 terdapat 5.484 ibu hamil dan $32,7 \%$ ibu yang mendapat tablet Fe. Presentase cakupan ibu hamil yang mendapat tablet $\mathrm{Fe}$ mengalami penurunan (Dinas Kesehatan Kota Tarakan, 2019). Berdasarkan uraian data di atas, maka maka peneliti mengadakan penelitian tersebut untuk mengetahui gambaran pengetahuan dan sikap ibu tentang pentingnya mengkonsumsi tablet zat besi selama masa kehamilan di Puskesmas Karang Rejo.

\section{Metode}

Penelitian ini adalah penelitian deskriptif, yaitu sebagai prosedur pemecahan masalah yang diselidiki dengan mengambarkan keadaaan subjek atau objek. Dalam hal ini peneliti ini ingin memngetahui gambaran pengetahuan dan sikap ibu hamil tentang pentingnya mengkonsumsi tablet zat besi selama kehamilannya. Lokasi penelitian ini dilakukan di Puskesmas Karang Rejo Kota
Tarakan, Kalimantan Utara pada bulan Mei 2019. Populasi pada penelitian ini adalah semua Ibu hamil di Puskesmas Karang Rejo pada bulan Mei 2019 yang mendapatkan yang melakukan pemeriksaan ANC (Antenatal Care) berjumlah 164 orang. Teknik pengambilan sampel secara purposive sampling yang memenuhi kriteria inklusi. Jumlah sampel dalam penelitian ini adalah sejumlah ibu hamil trimester kedua dan ketiga yang telah mendapat tablet zat besi sebanyak 50 orang/responden.

Dalam penelitian ini, informasi yang diperlukan didapatkan melalui data primer. Peneliti melakukan kunjungan ke lokasi penelitian dengan membagikan kuesioner untuk mengetahui pengetahuan dan sikap ibu hamil tentang manfaat mengkonsumsi tablet Fe. Kuesioner pengetahuan dan sikap ibu hamil tentang manfaat tablet Fe selama kehamilanya sebanyak 15 soal Aspek pengukuran meliputi data demografi responden yang harus dilengkapi meliputi umur, pendidikan, dan pekerjaan. Pada penelitian ini menggunakan analisa univariat untuk menghasilkan distribusi frekuensi dan persentase dari variabel dengan cara membuat tabel distribusi frekuensi. 
Yogho Prastyo, Mega Octamelia, Imelda Triyana. Pengetahuan Dan Sikap Ibu Hamil

Tentang Manfaat Mengkonsumsi Tablet Fe Di Wilayah Kerja Puskesmas Karang Rejo Kota

Tarakan

\section{Hasil}

Karakteristik ibu meliputi umur, pendidikan, pekerjaan dapat dilihat pada tabel 1 dibawah ini:

Tabel 1. Distribusi Frekuensi Responden Berdasarkan Umur, Pendidikan, Pekerjaan Tentang Pentingnya Mengkonsumsi Tablet Zat Besi Selama Kehamilannya di Puskesmas Karang Rejo.

\begin{tabular}{lcc}
\hline Karateristik & $\begin{array}{c}\text { Jumlah } \\
(\mathbf{n})\end{array}$ & $\begin{array}{c}\text { Presentase } \\
(\mathbf{\%})\end{array}$ \\
\hline & & \\
\hline 1. Umur & & \\
$<20$ tahun & 5 & 10,0 \\
$21-34$ tahun & 36 & 72,0 \\
$>$ 35 tahun & 9 & 18,0 \\
\hline Total & $\mathbf{5 0}$ & $\mathbf{1 0 0 , 0}$ \\
\hline 2. Pendidikan & & \\
SD & 7 & 14,0 \\
SMP & 12 & 24,0 \\
SMA/SMK & 23 & 46,0 \\
Perguruan & 8 & 16,0 \\
Tinggi & & \\
\hline Total & $\mathbf{5 0}$ & $\mathbf{1 0 0 , 0}$ \\
\hline 3. Pekerjaan & & \\
IRT & 28 & 56,0 \\
Wiraswasta & 16 & 32,0 \\
PNS & 6 & 12,0 \\
\hline Total & $\mathbf{5 0}$ & $\mathbf{1 0 0 , 0}$ \\
\hline
\end{tabular}

Penilaian terhadap responden untuk pengetahuan ibu hamil tentang manfaat tablet zat besi selama kehamilanya dapat dilihat pada tabel 2 berikut:
Tabel 2. Distribusi Frekuensi Pengetahuan Ibu Hamil Tentang Pentingnya Mengkonsumsi Tablet Zat Besi Selama Kehamilannya di Puskesmas Karang Rejo

\begin{tabular}{lcc}
\hline Pengetahuan & $\begin{array}{c}\text { Jumlah } \\
(\mathbf{n})\end{array}$ & $\begin{array}{c}\text { Presentase } \\
(\mathbf{\%})\end{array}$ \\
\hline Baik & 27 & 54,0 \\
Kurang Baik & 23 & 46,0 \\
\hline Total & $\mathbf{5 0}$ & $\mathbf{1 0 0 , 0}$ \\
\hline
\end{tabular}

Sikap ibu hamil terhadap pentingnya mengkonsumsi tablet zat besi selama kehamilannya dapat dilihat pada tabel 3 berikut:

Tabel 3. Distribusi Frekuensi Sikap Ibu Hamil Tentang Pentingnya Mengkonsumsi Tablet Zat Besi Selama Kehamilannya di Puskesmas Karang Rejo

\begin{tabular}{lcc}
\hline \multicolumn{1}{c}{ Sikap } & $\begin{array}{c}\text { Jumlah } \\
(\mathbf{n})\end{array}$ & $\begin{array}{c}\text { Presentase } \\
(\mathbf{\%})\end{array}$ \\
\hline Sangat Setuju & 17 & 34,0 \\
Setuju & 33 & 66,0 \\
\hline Total & $\mathbf{5 0}$ & $\mathbf{1 0 0 , 0}$ \\
\hline
\end{tabular}

\section{Pembahasan}

1. Pengetahuan Responden terhadap Pentingnya Mengkonsumsi Tablet Zat Besi Selama Kehamilannya

Berdasarkan hasil penelitian didapatkan bahwa pengetahuan ibu hamil tentang pentingnya mengkonsumsi tablet zat besi selama kehamilannya di Puskesmas 
Yogho Prastyo, Mega Octamelia, Imelda Triyana. Pengetahuan Dan Sikap Ibu Hamil Tentang Manfaat Mengkonsumsi Tablet Fe Di Wilayah Kerja Puskesmas Karang Rejo Kota

Tarakan

Karang Rejo termasuk dalam kategori baik (Tabel 2). Hal ini didukung oleh tingkat pendidikan responden, menurut Fuady dalam penelitiannya bahwa pengetahuan ibu hamil tentang manfaatzat besi dipengaruhi oleh tingkat pendidikan (Fuady \& Bangun, 2013).

Selain tingkat pendidikan, usia juga mempengaruhi pengetahuan seseorang, seperti yang terlihat pada hasil penelitian ini. Menurut Budiman (2013), usia mempengaruhi terhadap daya tangkap dan pola pikir seseorang. Semakin bertambah usia semakin berkembang pula daya tangkap dan pola pikirnya, sehingga pengetahuan yang diperolehnya semakin membaik.

\section{Sikap Responden terhadap} Pentingnya Mengkonsumsi Tablet

\section{Zat Besi Selama Kehamilannya}

Berdasarkan Tabel 3 menunjukkan bahwa dari 50 responden, 17 responden (34\%) sangat setuju dan 33 responden (66\%) setuju. Menurut Setyorini (2018) semakin tinggi pendidikan sesorang semakin baik juga sikapnya. Semakin tinggi pendidikan seseorang, maka seseorang lebih mudah menerima informasi sehingga dapat meningkatkan kualitas hidup yang dengan bersikap postif. Sebaliknya seseorang dengan tingkat pendidikan rendah, maka akan menghambat perkembangan sikap seseorang terhadap penerimaan informasi.

Berdasarkan faktor umur pada umur produktif umur seseorang maka sikap seseorang akan lebih baik dalam berfikir serta postif (Setyorini, 2018). Faktor yang dapat mempengaruhi sikap seseorang, misalnya pengalaman pribadi. Apa yang telah dan sedang kita alami akan ikut membentuk dan mempengaruhi penghayatan kita terhadap stimulus sosial. Tanggapan akan menjadi salah satu dasar terbentuknya sikap. Untuk dapat mempunyai tanggapan dan penghayatan, seseorang harus mempunyai pengalaman yang berkaitan dengan objek psikologis yang akan membentuk sikap positif dan sikap negatif. Pembentukan tanggapan terhadap obyek merupakan proses kompleks dalam diri individu yang melibatkan individu yang bersangkutan, situasi di mana tanggapan itu terbentuk, dan ciri-ciri obyektif yang dimiliki oleh stimulus. Untuk dapat menjadi dasar pembentukan sikap, pengalaman pribadi tersebut terjadi dalam situasi yang melibatkan faktor emosional (Budiman, 2013). 
Dalam menentukan sikap, setuju sebanyak 17 responden (34\%).

pengetahuan memegang peranan penting, sehingga sikap ibu terhadap pentingnya mengkonsumsi tablet zat besi selama kehamilannya dipengaruhi oleh pengetahuan yang dimilikinya., sikap baik yang ditunjukkan oleh responden ini dibuktikan dengan mereka memberikan respon yang baik dalam mengisi kuisioner tentang sikap ibu hamil terhadap pentingnya mengkonsumsi tablet zat besi yang dapat mencegah terjadinya anemia dalam kehamilan.

\section{Kesimpulan}

Dari hasil penelitian yang dilakukan tentang pengetahuan dan sikap ibu hamil tentang manfaat mengkonsumsi tablet Fe di wilayah kerja Puskesmas Karang Rejo Kota Tarakan sebagian besar responden memiliki pengetahuan baik tentang pentingnya mengkonsumsi tablet zat besi selama kehamilan, diperoleh sebanyak 27 responden (54\%) dan responden berpengetahuan kurang baik sebanyak 23 responden (46\%). Sebagian besar responden setuju tentang pentingnya mengkonsumsi tablet zat besi selama kehamilan, diperoleh sebanyak 33 responden $(66 \%)$ dan responden sangat

\section{Referensi}

Budiman, Agus Riyanto. (2013). Kapita Selekta Kuesioner Pengetahuan dan Sikap dalam Penelitian Kesehatan. Jakarta: Salemba Medika

Fuady, M., \& Bangun, D. (2013). Hubungan Pengetahuan Ibu Hamil tentang Anemia Defisiensi Besi terhadap Kepatuhan Mengkonsumsi Tablet Zat Besi. E-Journal FK USU, 1(1), 1-5.

Peraturan Menteri Kesehatan No. 88 tahun 2014 tentang Standar tablet Tambah Darah bagi Wanita Usia Subur dan Wanita Hamil. Diunduh pada tanggal 10 Mei 2019 . Diperoleh melalui sinforeg.litbang.depkes.go.id

Riset Kesehatan Dasar (2018). Badan Penelitian dan Pengembangan Kesehatan Kementerian Kesehatan RI Tahun 2018. Diperoleh dari www. depkes. go.id/

Rizki, F., Lipoeto, N. I., \& Ali, H. (2018). Hubungan Suplementasi Tablet Fe dengan Kadar Hemoglobin pada Ibu Hamil Trimester III di Puskesmas Air Dingin Kota Padang. Jurnal Kesehatan Andalas, 6(3), 502-506. 
Setyorini, A. (2018). Jurnal Komunikasi Kesehatan Vol.IX No.2 Tahun 2018. Jurnal Komunikasi Kesehatan Vol.IX No.2 Tahun 2018, 9(2), 58-64.

Susiloningtyas, I. (2012). PEMBERIAN ZAT BESI $(\mathrm{Fe})$ DALAM KEHAMILAN Oleh: Is Susiloningtyas. Majalah Ilmiah Sultan
Agung, 50, 128.

Tanziha, I., Utama, L. J., \& Rosmiati, R. (2017). Faktor Risiko Anemia Ibu Hamil Di Indonesia. Jurnal Gizi Dan Pangan, 11(2), 143-152. https://doi.org/10.25182/jgp.2016.11. 2. 